\title{
Georg B. Michels. 2021. The Habsburg Empire under Siege: Ottoman Expansion and Hungarian Revolt in the Age of Grand Vizir Ahmed Köprülï. Montreal: McGill-Queen's University Press, 2021. 603 pages.
}

\author{
Reviewed by Alexander Maxwell, Victoria University of Wellington, New Zealand \\ Alexander.Maxwell@vuw.ac.nz
}

The 1683 Ottoman defeat at the gates of Vienna proved such a turning point not only in the history of Hungary, but in the history of Central Europe generally, that the immediately preceding period has been somewhat neglected in the scholarly literature. In his new book, Georg Michels directly addresses these relatively understudied decades. The 1670 and 1672 Hungarian revolts against Habsburg rule form the central events of his narrative, and while the threat of Ottoman invasion looms ever-present in the background, Michels somewhat anticlimactically ends his narrative before the 1683 Ottoman campaign begins. Instead, he frames his narrative around the administration of Grand Vizir Ahmed Köprülü, who directed Ottoman affairs in the period 1661-1676. Geographically, Michels concentrates primarily on the northern parts of Royal Hungary, a territory larger than but roughly similar to contemporary Slovakia.

A narrative about Hungarian history can be framed around the career of a leading Ottoman politician because at the time the Ottoman Empire held the upper hand in the Danube basin. The Habsburg Empire, according to Michel's narrative, cowered before Ottoman might. It could neither pay or supply its soldiers nor properly maintain its fortresses, much less protect the lives and property of its Hungarian subjects. It could defeat Hungarian rebels, but only at Ottoman sufferance. Ottoman armies refrained from conquering Hungary only because they were occupied elsewhere, specifically fighting wars in Crete and Poland.

Michels nevertheless tells his story mostly from the Habsburg and Hungarian perspectives. He relies mostly on Habsburg and Hungarian sources, supplemented with an impressive mastery of the secondary literature. Michels can hardly be criticized for lack of language study: he cites sources in Hungarian, Latin, Italian, German, and Dutch; the footnotes additionally refer to historical works published in various Slavic languages, particularly Slovak. Nevertheless, he does not use Ottoman sources, and indeed suggests in his conclusion that "historians should turn to the Ottoman archives for further study" (345). Consequently, the reader perceives the Ottoman state essentially as it appeared to fearful Habsburg officials or hopeful Hungarian supplicants: the narrative makes Köprülü's decisions curiously inscrutable.

Ordinary Hungarians, by contrast, come vividly alive. In the aftermath of rebellion, Habsburg investigators interviewed witnesses, participants, and victims to Hungarian uprisings; several discussed with candor. Michels fully exploits these rich sources, and supplements them

$($ (c) $)$ EY

ULIS D-Sork 
Maxwell, Alexander. "Georg B. Michels. 2021. The Habsburg Empire under Siege: Ottoman Expansion and Hungarian Revolt in the Age of Grand Vizir Ahmed Köprülü. Montreal: McGill-Queen's University Press, 2021. 603 pages." Hungarian Cultural Studies. e-Journal of the American Hungarian Educators Association, Volume 14 (2021) DOI: 10.5195/ahea.2021.451

with diplomatic documents, spy reports, and aristocratic correspondence. He achieves an impressive and persuasive level of detail, all the while discussing with sensitivity various problems and omissions within the documentary record.

While his complex narrative resists concise summary, Michels places the Hungarian uprisings firmly in the context of Counter-Reformation religious persecution. Poorly paid Habsburg soldiers made themselves unpopular by plundering the countryside surrounding military strongholds and failing to protect people from Turkish slave-raiding, but imperial efforts to impose Catholicism generated a burning hatred among Protestants, which expressed itself in sectarian violence both during the 1670 and 1672 revolts and after their suppression. Scholars more familiar with the national conflicts of the nineteenth or twentieth century will be surprised by the near-irrelevance of ethnicity during Hungary's counter-revolutionary wars, which Michels fruitfully compares to similar sectarian conflicts elsewhere in Europe.

Hatred of the Catholic Habsburgs also generated pro-Ottoman feeling among Hungarians of all social ranks. Turcophile Hungarians established clandestine communication networks across the Ottoman-Habsburg frontier and raised armies in exile. Michels describes in somewhat exhaustive detail the movements of Hungarian exiles begging Köprülü and other Ottoman officials for protection and military assistance. Hungarian exiles clearly hoped that submission to the Sultan's rule might rid Hungary of Habsburg tyranny; protestants in particular judged the Turks more confessionally tolerant. The prevalence of Hungarian Turcophilia also challenges contemporary prejudices about European/Christian solidarity and the civilizational slope between Christian Europe and the Islamic world. Rebellious Hungarians not only paid Ottoman taxes and hoped for Ottoman military intervention, they wrote sycophantic odes to Turkish officials, adopted Turkish clothes, and even shouted "Allah" on the battlefield (285).

This book is thus written an impressive work of scholarship which both challenges popular memory and deepens scholarly understanding of a neglected period. Michels writes in readable, pleasant prose suitable for undergraduates, though the narrative provides such a wealth of detail that hypothetical course readings could be lengthy. Scholars working on Hungarian history will welcome the appearance of this authoritative work. 